\title{
5 System of Complex Control of the Level of Coordination Abilities
}

Many countries, including Germany, Russia, Poland, Czech Republic, USA and Japan have a rich experience in testing the motor performance of youth. The majority of research (Trzesniowski \& Pilicz, 1989; Strel, 1990; Przeweda \& Trzesniowski, 1992), however, concentrated on testing conditioning factors, while the level of coordination abilities is monitored only as part of the set (battery) of tests of conditional abilities, moreover, the sets mostly comprise only a single coordination test (overall or static balance test).

Works by Slovak and Czech researchers (Moravec, 1990; Moravec, Kampmiller \& Sedláček et al., 1996, and others) have brought interesting knowledge on motor performance of the school population, however, in the latest motor test battery used in Slovakia - EUROFIT - we can find only a single coordination test - "Flamengo test".

In spite of the fact that much information on coordination abilities has emerged recently, only a few have been devoted to the monitoring of these prerequisites for movement (Ljach, 1989; Belej \& Starosta, 1992; Kirchem, 1992; Belej et al., 1994) in children and youth between 10 and 17 years of age.

In Germany a group of experts on coordination under the leadership of Prof. Peter Hirtz elaborated test norms based on the measurement of over 1,300 children and youth and worked out age curves of coordination abilities.

It was discovered that when acquiring new sport skills (gymnastic, athletic, gamelike) experimental group of pupils aged 4 to 6 achieved on average better results than older children of control groups.

In Russia Ljach (1989) presents a complex methodology of assessment and development of coordination abilities in his book "Koordynacionnyje sposobnosti školnikov" (Coordination Abilities of School Children). Norms were presented in the article "Testy i normativy urovnej razvitija koordynacijonnych sposobnostej školnikov" (Tests and Standards of Development of Coordination Abilities in School Children) (1988). In Russia the terms "lovkost" (skillfullness) or "koordynacijonnyje sposobnosti" (coordination abilities) have been used.

In Poland the problem of testing was discussed by several authors (Trzesniowski \& Pilicz, 1989; Žak, 1991; Przeweda \& Trzesniowski, 1992; Raczek \& Mynarski, 1992; Szczepanik, 1993). They use the terms "koordynacja ruchowa" (motor coordination) and "koordynacyjne zdolnosci" (coordination abilities).

Results of international research were presented by Belej and Starosta (1992). They elaborated standards for 11 to 14-year-old children, while they used two analytical and synthetic coordination tests. In Czech Republic we can mention authors Blahuš and Měkota (1983), who in their book "Motorické testy v tělesné výchově” (Motor Tests in Physical Education) present several coordination tests. Norms of coordination abilities were presented also by the authors Kohoutek et al. (2005). 
In English written sources we can find only minor mentions on coordination abilities, which are denoted by the concepts "motor coordination", "coordination skills", "coordinative capacities" or "factors of coordination".

In Slovakia, the theory of coordination abilities has been developed by Kasa and Šimonek (1999), Šimonek, (1993, 1995), Belej and Starosta (1994), and others. In Central and Eastern European countries (Germany, Eastern Russia, Slovakia, Poland, Czech Republic, Hungary, Romania) the term “koordinačné schopnosti” (coordination abilities) is most frequently used, which replaced the older concept of "obratnostné schopnosti" (dexterities or skills).

In literature we can find a large number of coordination factors, but for didactic purposes there is a need to reduce their number. We will rely on the $\mathbf{7}$ elementary coordination abilities identified by Blume and Hobusch (1982) especially when describing the structure of sport performance. The seven abilities comprise:

1. Kineshetic-differentiation ability

2. Space-orientation ability

3. Rhythmic ability

4. Reaction speed

5. Balance ability

6. Ability to rebuild movement programmes

7. Ability to bind movement activities.

\subsection{Assessment of the Level of Coordination Abilities by Means of Performance Standards}

In school, physical education and sport standards have been used as the main tool of assessment. Under a "performance standard" we understand such requirements on the level of motor abilities of pupils, which are expressed in an operationalized form, i.e. they are concrete activities, which the pupils must know how to perform in order to reach the goal of learning. Performance standard is considered to be a performance norm for pupils they have to reach and is strictly defined.

For a coach it is not difficult to define performance standards in the sphere of conditioning motor prerequisites, for example, a 10-year-old boy should reach the result of at least $160 \mathrm{~cm}$ to pass in the Standing broad jump test, however, it is more difficult to specify coordination standards. How can we specify the measure - norm of expected minimum performance (i.e. the limit of passing or failing the standard) for example in rhythmic coordination ability?

When preparing performance standards of coordination abilities it is necessary to pay attention to the fact that coordination abilities have a complex character and they should be assessed in a complex way, i.e. in one whole. 
Based on a survey we elaborated performance standards for elementary coordination abilities (Šimonek, 1998) (Tab.1-14, Graphs 8-21 enclosed). For this purpose we set up a battery of 7 tests of coordination abilities, which includes the following rudimentary abilities: balance, rhythmic, reaction, space-orientation, kinesthetic-differentiation ability of legs and arms, ability to differentiate temporal parameters).

When assessing the level of coordination abilities we came out of the sum of assessment of individual coordination abilities, thus obtaining the complex picture of their level in individual age categories.

Performance standards of coordination abilities are evaluated in three levels so that an avarage and standard deviation are calculated and than, 3 performance standards are calculated for each age and gender category, separately for all 7 tests.

\section{Performance standards in individual tests represent:}

1. Minimum standard (MS $=$ arithmetic mean $+1.75 \mathrm{~s}$ )

Minimum standard upon coordination abilities stipulates minimum level of these abilities, which the individual should acquire in order to realize elementary skills, he is acquiring in volleyball.

2. Optimum standard ( $\mathrm{OS}=$ arithmetic mean $-0.75 \mathrm{~s}$ )

Optimum standard upon coordination abilities says that the individual has an optimum coordination prerequisites for the acquisition of motor activity, which forms a contents of sport preparation in the training process.

3. Performance standard (PS = arithmetic mean $-1.75 \mathrm{~s}$ )

Fulfilment of the performance standard signalizes to the coach that the individual reaches a high level of coordination abilities, which predestines him for top sport performances and is a prerequisite for fast and perfect mastering of even difficult coordination sport skills. Performance standards, which we submit herewith, in charts and graphs, are not statistic norms but logical limits characterizing minimum, optimum or special level of coordination abilities.

\subsubsection{Tests of Coordination Abilities}

Based on the recent experiments (Šimonek et al., 1994, Šimonek, 1997, 1998) as well as the experience of other authors (Hirtz, 1981) we can recommend the following set of tests of coordination abilities for the diagnostics of acquired results in the sport preparation of volleyball (Tab. 5.10).

\section{Test 1: Bench walk with 3 turns}

Description: The individual stands behind the $3 \mathrm{~m}$ long bench, which is positioned upside down, with their stronger leg up on the edge of the bench. At a signal they stand up on the bench and try to walk to the other side, while making three $360^{\circ}$ turns. If they loose balance, they can touch the ground but maximum two times (each touch represents one negative second aded to the final measured time), otherwise 
Table 5.10: Motor tests included in the set of coordination tests

\begin{tabular}{|c|c|c|c|}
\hline Test & Motor task & Coordination ability & Evaluation accuracy \\
\hline $\begin{array}{l}\text { T1 } \\
\text { Bench walk with } \\
3 \text { turns }\end{array}$ & $\begin{array}{l}\text { To walk along the bench } \\
(3 \mathrm{~m}) \text { as fast as possible } \\
\text { and to perform } 3 \text { turns } \\
\left(360^{\circ}\right) \text { on the way. }\end{array}$ & Dynamic balance & Time in sec. $(0.01 \mathrm{~s})$ \\
\hline $\begin{array}{l}\text { T2 } \\
\text { Stopping the } \\
\text { rolling ball }\end{array}$ & $\begin{array}{l}\text { After a } 180^{\circ} \text { turn to stop } \\
\text { the rolling ball as soon as } \\
\text { possible. }\end{array}$ & Complex motor reaction & $\begin{array}{l}\text { Distance in } \mathrm{cm} \\
(1 \mathrm{~cm})\end{array}$ \\
\hline $\begin{array}{l}\text { T3 } \\
\text { Movement rythm } \\
\text { observation }\end{array}$ & $\begin{array}{l}\text { To remember the specified } \\
\text { movement rhythm (rope } \\
\text { skipping) }\end{array}$ & Rhythmic ability & Time in ses. $(0.01 \mathrm{~s})$ \\
\hline $\begin{array}{l}\text { T4 } \\
\text { Shuttle run }\end{array}$ & $\begin{array}{l}\text { To orientate in space as } \\
\text { fast as possible while } \\
\text { touching three specified } \\
\text { numbered balls. }\end{array}$ & Space-orientation ability & Time in sec. $(0.01 \mathrm{~s})$ \\
\hline $\begin{array}{l}\text { T5 } \\
\text { Target standing } \\
\text { broad jump }\end{array}$ & $\begin{array}{l}\text { To jump with heels as } \\
\text { close as possible to the } \\
\text { mark. }\end{array}$ & $\begin{array}{l}\text { Kinesthetic-differentiation } \\
\text { ability of legs }\end{array}$ & $\begin{array}{l}\text { Deviation in } \mathrm{cm} \\
(1 \mathrm{~cm})\end{array}$ \\
\hline $\begin{array}{l}\text { T6 } \\
\text { Target sitting } \\
\text { throw }\end{array}$ & $\begin{array}{l}\text { To throw as close as } \\
\text { possible to the specified } \\
\text { mark. }\end{array}$ & $\begin{array}{l}\text { Differentiation ability of } \\
\text { arms }\end{array}$ & $\begin{array}{l}\text { Deviation in } \mathrm{cm} \\
(1 \mathrm{~cm})\end{array}$ \\
\hline $\begin{array}{l}\text { T7 } \\
\text { Time estimation }\end{array}$ & $\begin{array}{l}\text { To stop the stopwatch as } \\
\text { close to the } 5 \mathrm{~s} \text { mark as } \\
\text { possible (without watching } \\
\text { it) }\end{array}$ & $\begin{array}{l}\text { Estimate of temporal } \\
\text { parameters }\end{array}$ & $\begin{array}{l}\text { Deviation in sec. } \\
(0.01 \mathrm{~s})\end{array}$ \\
\hline
\end{tabular}

they must repeat the test. Time from the starting signal to the touch of the ground behind the bench is measured. One preparatory and two measured attempts.

\section{Test 2: Stopping the rolling ball}

Description: 2 benches ( $5 \mathrm{~cm}$ distance between them) are leaned on a shell-board at a height of $120 \mathrm{~cm}$ so that a volleball ball can be rolled down between them. On the surface of one of the benches is attached a gauge (meter). Examiner holds a ball at the top of the meter. The individual stands concentrated on a starting line, $150 \mathrm{~cm}$ from the lower edge of the benches with theirback to the running direction (they do not watch the ball). The examiner on audio signal allows the ball to roll down the benches gap and the task of the tested person is to stop the ball with both hands as fast as possible. 1 preparatory and 3 measured attempts, the best one is recorded. 


\section{Test 3: Movement rhythm observation}

Description: Player skips over the rope for 20 s in a certain tempo, which they choose. The examiner counts number of rope skips during the given period. In the second part of the test the tested person carries out the same number of skips as in the first part. The examiner measures the time fow which the subject fulfils the task. Deviation from 20s will be the criterion of success in the given test. In the case that the participant makes an error and fails to jump over the rope, he can repeat the test only once. When testing the pupils of elementary school we recommend not to use a skipping rope but to carry out the test only as an imitation of skipping (without a rope).

\section{Test 4: Shuttle run}

Description: 6 medicine balls are arranged in the following way: one is in the centre, numbering of the others is free and prior to each measurement we change the positions of the balls. Player starts from the standing position with the back to the balls. Having called one number out of 5 the subject runs to the ball with the called number and touches it, and returns back to touch the ball No. 0. At the moment of touching the 0 ball, the administrator calls another number of the ball (1 to 5). The same is repeated with the third number of a ball. The test finishes with the touching of the ball in the centre after the return from the third ball. Better result out of the two measured times is recorded. One preparatory trial is allowed.

\section{Test 5: Target standing broad jump}

Description: Athlete jumps to a maximum distance (2 attempts). After marking the $75 \%$ distance of the maximal performance the subject tries to jump forward, landing the heels as close as possible to the given $75 \%$ mark. One preparatory and three measured trials. An average of three measured results is recorded.

\section{Test 6: Target sitting throw}

Description: On the surface of a playground we stretch a measuring tape (50 m long). The tested person is sitting on the basic line and gradually throws 2 attempts with a tennis ball at the maximum distance. The better result is recorded. In the second part of the test the $50 \%$ of the maximum result is marked on the floor. Athlete throws other 10 attempts into the target on the ground. A deviation (absolute value) from the $50 \%$ mark is recorded. The level of the measured motor ability is expressed by the average sum of 10 deviations.

\section{Test 7: Time estimation}

Description: The tested person at first tries to measure time on a stopwatch. They start the stopwatch and watching the hand try to stop it at the $5 \mathrm{~s}$ mark. Then they try to repeat it without any visual control. One preparatory and one measured attempt. Deviation (in sec.) from the $5 \mathrm{~s}$ value is measured and recorded.

The majority of the recommended tests (T1-T5 and T7) can be conducted in a gym, indoor, or outside, on a playground. The test $\mathrm{T} 6$ of kinesthetic-differentiation ability is an exception. It is administered outside, since it needs a longer area for its realization. 
The battery of coordination tests includes those verified by the group of German researchers who stipulated the basic statistical characteristics (reliability, objectiveness, validity and economy) on a sample of approximately 1,300 pupils in age categories from 7 to 24 years. These are tests No.1, 2, 4, 5 and 7. Test No. 3 was described by Dropčová (1987), test No. 6 was taken over from Ljach (1989), who verified it on 1,617 tested persons. Selected characteristics of the test: $r_{\text {stab. }}=0.62$. Three preparatory and 10 measured trials are recommended.

German authors described these characteristics of the reaction test (T-2): logical (contents) validity: assessed by experts and literary sources, factor validity: 0.48, construct validity: 0.48 - together $0.96 \%$ validity, reliability of the test: (method testretest): 0.83, objectivity: exactly measurable registration of results. Hirtz (1985) used the test covering space-orientation ability as well as partly also acceleration speed and explosiveness of legs (T-4) under the title Shuttle run. Měkota and Blahuš (1983) revealed test results: $r_{\text {stab. }}=0.88$ and $r_{\text {obj. }}=0.84$ while they recommend one preparatory and two measured attempts. Test of differentiation ability of legs is presented by Sehlbach (1988) under the title Target jump down. It is a modification of the test by Měkota and Blahuš (1983). It is important that a feedback is assured after each trial in the tests of differentiation ability.

The test Time estimation (T-7), which was set up by Komárik (1987), captures the ability of the tested person to estimate temporal parameters - to correctly perceive a certain time interval. It records central components of movement control such as motor thinking, motor memory and timing of movements.

\subsubsection{Using Standards and Tables}

When using the enclosed standards and tables, the following procedure should be observed:

- $\quad$ select a suitable table as to the age and gender of the athlete,

- compare the reached result (performance) with the standards in the particular table gradually in all tests of the battery,

- $\quad$ assess the reached level of the standard and specify the resulting assessment based on the scored number of points for the reached standards in individual tests,

- $\quad$ assess the performance of the player according to his health state, conditions for sport preparation and sport specialization,

- $\quad$ for the recording of test results use the sheet "Personal trainer of the volleyball player" (p. 60).

Example: Participant XY is 11 years old and reached the optimum level in all tests and in the test of kinesthetic-differentiation abilities he overcame the limit of top performance standard. That means that he has high prerequisites for such sport game, 
in which kinesthetic-differentiation abilities are the limiting factor of the structure of sport performance (e.g. basketball, ice-hockey, tennis, and also volleyball). From the point of view of the school sport such individual is evaluated as excellent.

\section{PERSONAL TRAINER OF THE VOLLEYBALL PLAYER (battery of coordination tests)}

\begin{tabular}{ll}
\hline Name: & Date of birth: \\
\hline Body height: & Body weight: \\
\hline BMl: & Date of testing: \\
\hline
\end{tabular}

\begin{tabular}{|c|c|c|}
\hline Test - measurement: & Result: & Fulfilment of the norm: \\
\hline T1: Bench walk with three turns & & \\
\hline the rolling ball _ _ - & & \\
\hline T3: Movement rhythm observation & & \\
\hline T4: Shuttle run & & \\
\hline T5: Target standing broad jump _ _ & --- & \\
\hline T6: Target sitting th & & \\
\hline T7: Time estimatio & - - - & 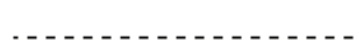 \\
\hline
\end{tabular}

Assessment in the tests:

M-minimum level / 1 point/

O-optimum level /2 points/

P-performance level / 3 points/

Total score of the battery: $B=\$ 1+\$ 2+\$ 3+\$ 4+\$ 5+\$ 6+\$ 7=7-21$ points

Difference score: $D=S_{\max }-S_{\min }$

Total assessment of the battery:

Minimum performance: 7-10 points

Optimum performance: $11-17$ points

Competitive performance: $18-21$ points

Personal recommendations:

Total level of coordination abilities:

Best developed coordination abilities:

Least developed coordination abilities: 